\title{
Conflicts within Capital and the Motivations of Climate-Interested Investors
}

\author{
David Peetz \& Georgina Murray
}

The corporation under capitalism has been described as an "externalizing machine" (Bakan, 2004). Since the industrial revolution, profits have relied upon not only the ability to extract surplus value but also the ability to internalize benefits while externalizing at least part of the costs of production - that is, others, including nature, have borne some costs of the production process. Poisoned rivers, ill and injured workers and toxic wastelands are examples of the ways in which costs have been externalized. Nature is treated as if it were unlimited and inexhaustible. The most significant historical example of externalizing costs is the climate crisis, as for the past three centuries owners of capital have directly and indirectly emitted carbon into the atmosphere without paying for any of the cost that these emissions cause. That crisis now threatens the existence of capitalism (Liodakis, 2010; Wright and Nyberg, 2013). Our chapter investigates whether, and more particularly why, some parts of finance capital may be motivated to interrupt this process and attempt to avert the climate crisis.

The climate crisis can be distinguished from other examples of environmentally destructive behavior by capital in two important respects. First, it is a transnational crisis that lacks geographic specificity. The climate crisis arises from the effects of multitudinous events, across hundreds of states and billions of actors, upon the global ecosystem. Whereas direct, locational regulation of corporate decisions (banning logging in certain areas, proscribing the maximum toxic composition of waste flows into water courses, etc.) may be a way for state policymakers to obviate or sometimes prevent most environmental externalities, the sources of climate emissions are too numerous and diverse, and the costs imposed across too many countries remote from the emitters, for traditional regulation to work in the absence of some other intervention.

Second, whereas many forms of environmental degradation may impose costs upon or even threaten the existence of individual communities, local ecosystems, even other capitalists, the climate crisis threatens to disrupt the global economy within which capital exists. Capital has transnationalized, and global economic returns become more important for a transnational capitalist class than for individual nation-based capitalists. It is not possible for mobile capital to escape Earth: "there's no business to be done on a dead planet" (Brower quoted in Nahser, 2013). The effects of climate change would be "severe, far reaching, and...affect the most physically and economically vulnerable disproportionately" (Semenza, 2011) and humans are critically responsible (Barker et al., 2013; Hansen et al., 2013; Intergovernmental Panel on Climate Change, 2007; Stenhouse et al., 2013).

The first of these distinctions (the unique dispersion of climate change emissions) means that regulatory interventions that price carbon emissions (either through carbon taxes or emissions trading schemes) are an essential part of any attempt by states to address the climate crisis. The second (climate change's terminal inescapability) means that there will be, within capital, conflict between those capitalists who benefit from emissions, and those whose future profitability is threatened by substantial climate change. It also means that the latter fraction may, in part, seek to promote interventions that price carbon emissions as a strategy to protect future profits - even in parts of capital that otherwise eschew state intervention as an intrusion upon their profitability. Thus while some write of "creative selfdestruction" (Wright and Nyberg, 2013) by capital, it is important to not only recognize that 
conflicts exist within capital but also to ask whether those conflicts indicate possible points of leverage for those seeking to address the climate crisis.

The focus of attention in this chapter is finance capital, the heart of global capitalism and in some key respects the core of the transnational capitalist class (Peetz and Murray, 2012). It is finance capital that funds accumulation by the rest of capital, through debt and equity. Indeed, amongst the world's largest corporations finance capital owns the greatest part of industrial capital (Peetz and Murray, 2012). Finance capital has been endemic to capitalism in cyclical waves since the $16^{\text {th }}$ century (Mandel, 1972) but has re-emerged triumphant in the post 1980s period - a period marked as the end of the Keynesian Compromise and the beginning of the dominance of economic liberalism and "financialization". The latter is "a pattern of accumulation in which profits accrue primarily through financial channels rather than through trade and commodity production" (Krippner, 2005:174). Marazzi (2011) calls this recent period a "revolution won by finance" whereby "the financial economy today is pervasive with a casino of investment instruments: derivatives, swaps, future markets, hedge funds, debt transfers (also Henwood, 1998; Strange, 1986).

Financialization has an economic liberal free market ideology that has been popularized by and amongst policy makers in most industrialized societies. This ideology is most closely associated with finance capital (Chan, 2013), the economic share of which has grown most substantially in the economic liberal era (Freeman, 2010). Part of this ideology has included several "political myths" about the beneficial or irresistible role of corporations and capitalism (Wright and Nyberg, 2013)., Climate change denialism, especially persistent in the U.S., has a heavy ideological component (Gauchat, 2012) and, at the individual level, is strongly associated with free market ideology or conservatism (Lewandowsky, 2013; Kahan et al., 2012; Hmielowski et al., 2013).

Yet while free market ideology usually serves the interests of finance capital well, the long term interests of significant parts of finance capital are endangered by the growth of carbon emissions and hence by the untrammelled operation of the market. Some are directly threatened by climate change, especially insurers who have faced rapidly rising expenses from weather events since the 1980s (Reguly, 2013). Others are indirectly threatened by the social costs and lower returns arising from climate mitigation, population displacement, ocean acidification, political disruption and other climate effects, or even the possibility that parts of the economy may become financially unviable (e.g. agriculture) or uninhabitable (Hansen et al., 2013). Hence fractions within finance capital might seek to modify capitalism, including if necessary through support for regulation, to avert climate risk and ensure the capacity for long term returns. For this to happen, those parts of finance capital must first identify the link between current accumulation and climate change, and the threat that this poses to future accumulation. They must then create new mechanisms or structures that will decouple accumulation from climate change, so that accumulation can occur without advancing the climate crisis.

Within the discourses involving capital, this issue is often located within debates on "responsible" or "ethical investment" or "sustainability" that extend beyond climate issue to encompass what is often referred to as the "triple bottom line", or "environmental, social and governance" (ESG) issues (Esty and Winstone, 2006). ESG has a history that can be traced back to individual 18th century capitalists (Donnachie, 2000; Randall Morck, 2005; Macqueen, 2004). While growing commitment to "sustainable development" or a "green firm" is apparent (connected no doubt to the perceived profitability) (Lubin and Esty, 2010), there is no global standardization of what constitutes sustainable corporate development 
(Cowan et al, 2010:524). The route into ESG for many corporations has been through the need to address reputation costs of inaction. On climate change, however, the terminal inescapability of the issue has engaged parts of finance capital, regardless of their prior ESG position.

Lever-Tracy (2011: 45-46), points to the possibility that capitalism might avoid selfdestruction if resources are redirected into retooling energy and transport systems, science and research. The problem she identifies is the contemporary liberal economic and political framework and the associated "pervasive trend... of the fore-shortening of time in economic calculations" (Lever-Tracy, 2011 46). Short-term considerations motivate not just corporate CEOs but also policy makers.

The climate crisis, then, can be seen in the context of conflicting capitalist visions between short-term profit and long-term considerations. "Agile capital" exercises power "not through voice, as in the taking up of directorships in affiliates, but through exit - the threat of capital withdrawal if adequate profit is not forthcoming" (Carroll 2007:13) Companies experiencing higher share price volatility appear less likely to engage in behavior indicating awareness of climate issues (Peetz and Murray, 2013). Agile capital is antithetical to dealing with climate change. It is least amenable to managing externalities or adopting long-term horizons. Indeed, increasing short-termism could arguably be exacerbating climate change. Yet in earlier, quantitative research we established that climate-interested investors (CIIs), who had signed up to various instruments and institutions actively engaged in addressing climate change, accounted for well over a third of the ownership of the world's very large corporations. We also showed that more activist CIIs may make a difference to carbon behavior of target corporations where their shareholdings are large enough to enable them to exert power, at or above around 1.5 per cent of a target company's shares (Peetz and Murray, 2013). What is needed is deeper investigation of the motivations and methods of these climate-interested investors.

So how do we conceptualize the factors that, in the face of the focus on short-term profits, create a longer-term focus that may enable the climate crisis to be addressed? A depiction of the possible factors influencing finance capitalists' investment behavior and change the way some behave is provided in Figure 1. In particular, we look at factors that influence the when of investment -whether the time horizon applied is short term or long term - and the what of investment -whether "costs" and "returns" incorporate purely orthodox criteria or also take account of such factors as carbon emissions or climate risk.

At the bottom of the figure we see two sets of factors relating to investment - the demand for investment services and returns on investment. The nature of clients is likely to influence demand for investment services and hence investors' climate behavior. Negative reputational effects from unpopular decisions can also be influential. The ways in which climate change affects their returns on investment will also shape investment behavior. 


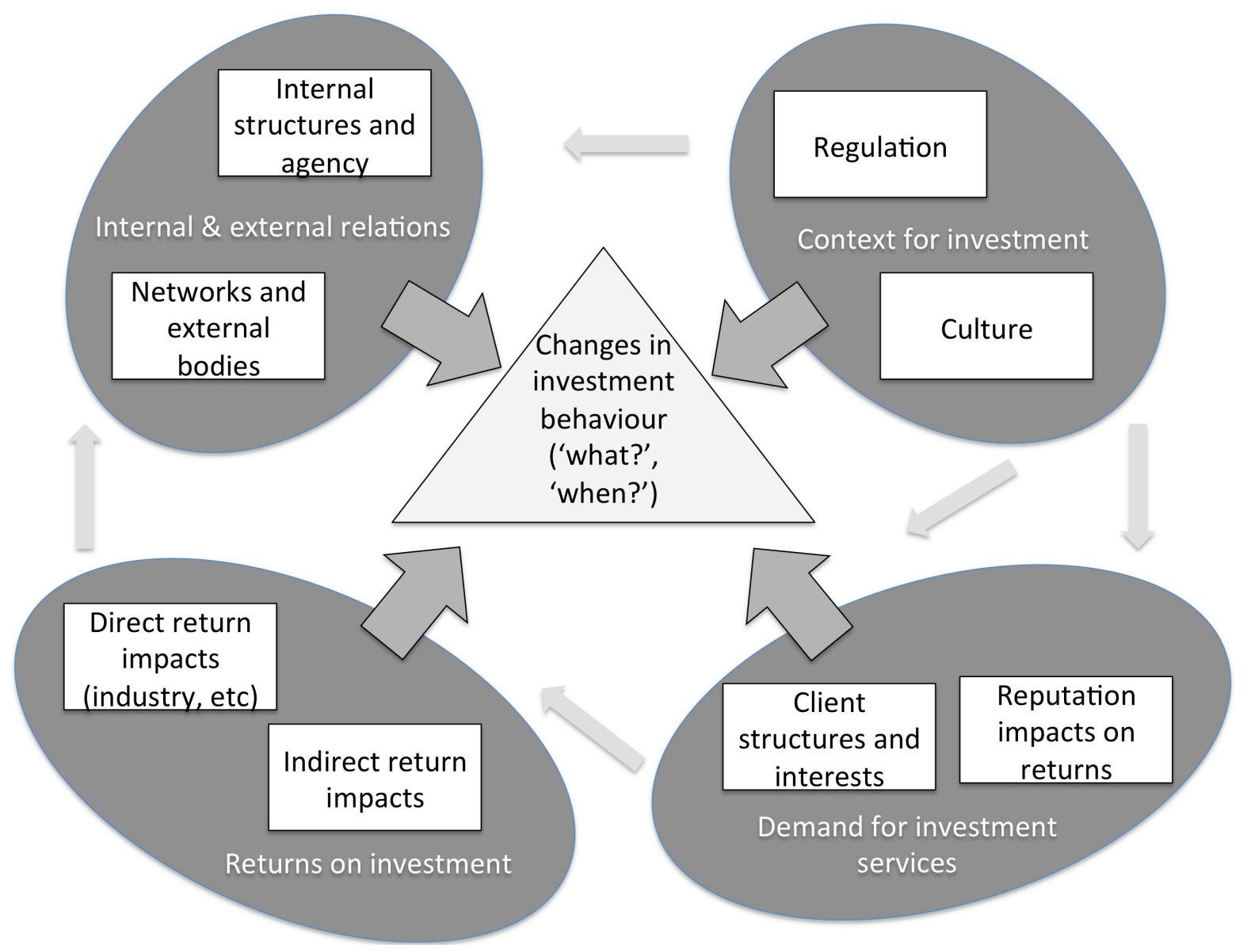

Figure 1 Potential influences on investment behavior relevant to climate

Structure and agency, within the organization and between the organization and others, also matters. A finance corporation may be more likely to have a longer time horizon and take account of a wider range of considerations if it contains specialist units, or follows specialist procedures (e.g. mechanisms for calculating or incorporating climate effects) for dealing with climate considerations, or has managers in key leadership positions who give priority to these issues, or is involved in external networks that give it access to specialist advice and knowledge. These structures can embed (relatively) climate-friendly practices, and individuals within them can exercise agency that affects investment decisions. Within the top business sector there are climate investor non-government organizations ("CINGOs") who campaign to mobilize capital (especially finance) to address climate issues. They accept that humans have crucially contributed to global warming and that top business can be motivated to help halt this trend and seek to educate corporations and individuals to sustainable and ethical investment. These "alternative think tanks" developed a concentrated political focus in recent years, and include such bodies as the Carbon, Disclosure Project [CDP], United Nations Principles for Responsible Investment [PRI] and other institutions concerned with environment, social and corporate governance issues. While CDP's focus is exclusively on climate, PRI encompasses a broader range of ESG issues. Large and small players may also be signatories to such instruments as the 2011 Global Investor Statement on Climate Change or belong to networks such as the Investor Network on Climate Risk.

In the top right hand quadrant of Figure 1, we see the impact of the legal, regulatory, economic and cultural context. We have already mentioned the potential impact of 
regulation. In addition, different nations are associated with different cultures (Hofstede, 1984), and even in a "globalized" world, the home countries of investors might affect the matters they take into account. The state of the economy may also influence how much space is given to climate issues. The thinner arrows in the chart in turn suggest how the regulatory and cultural context may affect the other factors influencing investment behavior, and how all may influence the internal structures within a financial corporation.

As a result of the unique dispersion and especially the terminal inescapability for capital of the climate crisis, fractions of finance capital are being forced into change. Our chapter does not argue that such changes within finance capital will or could be an adequate response to the climate crisis. Indeed, those parts of finance capital that are attuned to the crisis recognize this fact themselves. There is a widespread literature on the incompatibility of capitalism with ecological wellbeing or sustainability (Liodakis, 2010: 101-139) which we cannot interrogate here. Our interest is much more specific: in the factors that motivate individual owners or agents of capital to action.

Hence in the remainder of this chapter we investigate the factors shaping this fraction of finance capital that seeks to decouple climate change from accumulation, and promote a long-term survival orientation - what we call a sub-class of "climate-interested investors" (CIIs). Our attention is focused on several of the larger institutions. There are other CIIs who are much smaller individually but networked through such bodies as the Global Alliance for Banking on Values (GABV), a network of 25 banks, credit unions and building societies that share a commitment "to promote a positive, viable alternative to the current financial system". We investigate several of the factors influencing investment behavior in larger financial corporations, as shown in Figure 1, including their responses to state intervention. We consider choices between state regulation in support of "long-term" capital versus individual self-regulation in the interests of "short-term" capital, as well as the emergence of environmental NGOs lobbying for voluntary collective self-regulation. Unusually, it seems this form of collective self-regulation is not seeking to supplant external state regulation but rather to facilitate it in order to facilitate continued accumulation. In short, we ask: what motivates this fraction of finance capital?

\section{Methods}

This chapter represents part of a larger project on finance and climate change. (See Peetz and Murray, 2013.) It involves qualitative and quantitative data. The latter was mentioned above, and utilizes our "Finance and Climate" Database derived from datasets relating to corporations and carbon disclosure. Our qualitative data, upon which most of this chapter is based, are derived from fieldwork undertaken during 2012. We interviewed ten people in the financial sector, through seven face-to-face and telephone meetings from June to August. The participants were largely interviewed in or at their bases in Canada, the UK, France and the USA. The interviews covered senior people from five significant finance corporations (two banks, two insurance companies and a broadly based financial corporation), mostly in positions equivalent to managers or vice presidents of responsible investment, and two institutions seeking to promote, amongst other things, investment in climate-friendly activities. Using a semi-structured interview protocol we asked a range of questions relating to motivations, investment techniques and decision-making, returns, and the corporate and international politics of climate change investment. With permission of participants, all bar one were recorded and transcribed (in the other, extensive notes were taken rapidly). Six respondents were male and four female. 
On terminology, we use "CII" to refer to the organizations, and "CII managers" to refer to the climate-interested managers, like the financiers we interviewed, within those organizations. We refer to the corporations in which finance capital invests as "target" companies. To preserve anonymity, in the text below we label our interviewees with letters and a prefix indicating whether they worked in finance capital corporations ("Financier A" etc) or for a climate-investor non-government organization ("Cingo A" etc). The financiers came from corporations with a varying degree of engagement in climate issues. Using a term from our earlier, quantitative research we would say that Financiers B and D were from highly "activist" climate-interested investors, Financiers A and E were from climateinterested investors that were low in activism, while Financier $\mathrm{C}$ was from an organization somewhere in between, though closer to A and $\mathrm{E}$ than to B or D. Our financiers were all from large, mainstream financial corporations, all within the top ranked institutions in their home countries and two within the top ten by value of corporate ownership in the world.

\section{The what and when of climate-interested investors}

Our respondents showed a resigned awareness of a struggle within finance capital to broaden the conceptualization of the "what" and "when" in investment decision-making. On the disconnect between profit and principle, one spoke of

The definition of profit and the definition of capital...the council are saying "yeah" there are six forms of capital its not just financial capital... in many ways our accounting model is still based on the concept of capital that went out with the last Vanderbilts". ${ }^{1}$ [Financier C]

This respondent referred to the negative effect of orthodox economic training

When you're in your early 20s and you're learning about the Chicago school of economics it never occurs to you, because you don't have the knowledge, to question some of the assumptions being made. And then, by the time you've got the knowledge to challenge those assumptions, you're already deeply steeped in the Chicago school of economics. [Financier C]

Some CII managers perceived a "trade off between ESG concerns and returns" [Financier A], though others challenged this perspective. Most, though, saw the importance of their company's bottom line and of whether a matter was sufficiently "material":

It's all about financial...It's not about natural capital costs at all. It's not about biodiversity and the impact on ecosystems, that's not how [the bank thinks]... partially because you can't really quantify those things. So if you can't quantify it then how can you really account for it in a way that's consistent and makes sense? [Financier A]

The other key problem was neatly summarized by Cingo A who said, "short-termism is the biggest problem with the existing system". Another described more explicitly the way that the institutional basis of the fund manager affected time horizons:

The guys in the team that I was working with directly, when I first started in the Netherlands... were the in-house team for a long-term pension fund, which [meant] 
that their investment horizon and the way they thought about their expectations of companies when they invested were very different from the people in London, who were in an external investment management company working for clients who had given them short-term performance objectives. The performance objectives given to the in-house guys at the fund in Amsterdam were longer term... They really had to work very, very hard to understand the long-term factors that were going to affect companies' performance, not just the things that were going to drive the share price over the next six months or so. [Cingo E]

\section{Demands for investment services: Reputation effects}

When we asked the CIIs what motivated their firms to comply with ESG they gave us a variety of answers starting with the official line, for example:

I think sustainability issues are ... well ingrained because they've been that way for a long time. They may not have been called that, you know, they've been called other things. They've been called corporate governance. They've been called employee rights. They've been called health and safety. But it's been going on for a long time.... Companies and corporates have always given back and they've always tried to give back. [Financier A]

The CINGOs take advantage of the "reputational impact of being seen by the consumer" as acting on climate issues [Cingo A]. Companies "want to be seen to be at the top of their sector". Hence for Financier E, critical risks taken into account in corporate governance have been both reputational and financial. Financier A said that, as the resident ESG person within her corporation, she was contacted when a social or environmental issue had implications for its reputation. If people were to vote on the board on an awkward issue in this area she would likely be co-opted in to giving her opinion. According to Financier A every case is different because "you can't measure [reputation effects] really" and so "till the horse leaves the barn you have no idea what the impact's going to be." Hence:

The only way you can really manage reputation impact is to fully understand everything that could possibly happen... So it's a case by case and there's a committee and there's senior people and there's lot of conversation and lots of back and forth as to whether it's tolerable. [Financier A]

In CIIs with lower climate activism, reputation effects appeared to be a larger consideration or at least, a stronger weapon for climate advocates within the organization. There were not given prominence by Financiers B or D.

Indeed, if reputation effects were all that drove the interests of finance capital on this issue, we could not speak of any fundamental changes in behavior or conflict between parts of finance capital. The overwhelming majority of the world's 250 largest firms engage in some form of ESG reporting, most likely for reputational reasons, and the most common risk identified by large firms (and by finance firms within that group) is reputational risk (KPMG International, 2013). There is already a substantial body of research showing that many firms seek to "green wash" their reputation - make it look like they are concerned with the environment while behaving in the opposite manner (eg Pearse, 2012; Bakan, 2004). Some firms may take up environmental issues as a means of offsetting negative publicity in other ESG areas (eg Wal-Mart is active on environmental issues but regularly criticized for major 
breaches of labor rights) (Carroll, 2013; Entine, 2008; Vandenbergh, 2007). Hence there is some evidence that firms who perceive themselves as having a high reputation on CSR may be more likely to engage in socially irresponsible behavior later (Ormiston and Wong, 2013). However, the motivations underlying climate-interested behavior for those we investigated went well beyond reputational effects.

\section{Demands for investment services: clients}

Investors can be split into two broad types. "Asset owners" (who own capital available for investment) and "investment managers", sometimes known as "fund managers", who will invest capital on behalf of asset owners. Some asset owners will invest funds directly (eg by purchasing shares in individual companies), but often their funds are lodged with investment managers. Large finance corporations may perform both functions through different entities. Asset owners themselves are of two types: those in the retail market (often individuals or industrial corporations) and those in the institutional market (eg public or private pension funds). As clients of investment managers, asset owners play a critical role. There are interesting and, at times, contradictory roles played by these actors. On the one hand, pension funds have to maximize returns for their members, whereas individuals in the retail market might, by personal choice, give priority to ESG issues, opening the door for dedicated ESG funds.

What does your client want? If it's a retail client you might well be able to take a harder line in sustainability terms... The retail market supports, generally speaking, a wider range of sustainability options, than the institutional market in the sense that institutional clients, like pension funds would always have very strict risk tolerances ...An institutional investor is run by a bunch of trustees who have fiduciary responsibilities laid down in law. So they can't just say, "I think climate change is terrible, therefore we won't invest in fossil fuel," unless they've got an absolutely crystal clear mandate from their own beneficiaries. [Cingo E]

On the other hand, as we saw, pension funds must be concerned with returns many decades into the future, so there is a need to factor in longer-term considerations. Hence a number of CIIs saw them as a key agent for sustainable futures:

As they are going to have to be paying out dividends and paying out the pensions in a number of years as an industry, [they need] to have a climate change specific environmentally friendly position as overall they are going to need to get those longterm returns. So I think they will be increasingly a voice in this debate about the move away from the short term-ism. [Cingo A]

As a general point, some CII managers expressed frustration with the equivocal stand of some clients and their failure at times to "put their money where their mouth is". Thus:

The really important thing from an asset management perspective is getting a really clear message from our clients of what they expect...I hear when I go to [ESG] conferences and I'm talking to our clients... And they go, "Oh, this quite important stuff, and we really believe that so on and so on." But they don't say that same thing to their client relationship manager or their portfolio manager when the portfolio manager comes to present to them. So there's this disconnect ... If they had enough clients 
saying, "This is very important to us and we believe that the carbon footprint of every company in there should be monitored"... then the portfolio manager's going to work out how to do that. If they don't say that then portfolio managers will assume that it's not of interest.'[Financier C].

The same person noted the internal implications of the sometime distinction between the public statements and private (in)actions of some: "Unless shareholders make these comments to the CEO, the CFO and board member then my department doesn't get funded adequately; same thing, and it's true" [Financier $\mathrm{C}$ ].

The absence of secure retirement incomes in North America was seen as an impediment to action amongst many individual asset owners. Hence Financier A commented that, in the USA:

The notion of a company pension is antiquated, and definitely the notion of a defined benefit company pension ... there's hardly anybody that has that. So people are worried about how they're going to retire...So, making choices, they're singularly focused on the return.

She added that such considerations were also relevant to her, at a personal level, and noted the limited opportunity to invest in funds in her own country that met all the relevant criteria. However, Financier $\mathrm{C}$ noted the circularity of the client-fund manager relationship. At a recent meeting she observed:

As ever, "it's always somebody else's responsibility to move first" was actually the overriding message. So for instance...the asset managers said that the asset owners need to make clearer the pricing signals around integrating ESG and for investment decision-making; and the asset owners or the pension funds said, "Well, asset managers need to provide more product that we can invest in".

The perspectives of pension funds also shaped the products offered by investment managers:

If you turn your sustainability dials too far towards the deep green end and say, "I'm simply not going to invest in any company with emissions above a certain intensity or no fossil fuel at all," or whatever, then that would mean that your portfolio would be very high risk in financial terms and probably not something that you would be able to sell to an institutional client. [Cingo E]

Financier C, from a large fund manager firm, was more specific on client demands, and also on the priority often given by clients to other ESG issues:

We do have some funds that we manage based on client's investigations, so clients will say generally, that they want to exclude some industries or factors, and we implement those strategies for them. But that's much less often around environmental issues than around social issues or ethical issues... They're much more likely to be things like not investing in weapons manufacturing... Or not investing in tobacco and alcohol, those sorts of things.

There were also perceived limitations on the analytic capabilities of pension funds: 
In a context where ... you've got all those compliance issues ... it's just another thing to worry about that doesn't seem like a top priority... But they're underfunded and they are under resourced, they haven't got many people [Cingo E]

Overall, our CIIs tended to be ahead of clients on climate issues. When we asked Financier B why his corporation had taken such a prominent role in ESG issues, he said:

It's not quite demand, I wish it were. Peer pressure, regulatory trends and doing the right thing.

His response points to the importance of networks, individual agency and regulation, all of which we consider later. In sum, clients' interests and behaviors made a big difference to the actions of fund managers. Even climate-interested fund managers would be unable to act if their clients disagreed, which could occur if they were focused only on short-term or financial returns. The latter might even be the case amongst pension funds, though public or (as mentioned below) union-related pension funds may be inclined to take the broader and longer term perspective that would be conducive to climate action.

\section{Impacts on investment returns}

CIIs showed understanding of the direct and indirect financial implications of climate change. One discussed how their work involved ensuring

Companies are taking into consideration the long-term impacts of their business and therefore their sustainability in a financial sense as well as in a wider economic and community sense. And that is all part of fulfilling our fiduciary duty and ensuring that we generate returns [Financier C].

There was little doubt seen about the reality of climate change or its impact on returns.

In certain markets there might still be skepticism about the science. Yeah, but only one market [the US]. In the case of most of the public sector pension funds in that market, in the US, there probably isn't too much skepticism about the science. [Cingo E]

It is not surprising. For example, reinsurers, according to a leading scientist, "have been leaders on climate change for a long time... We should give them credit because they raised the awareness of climate change for governments" (McBean, quoted in Reguly, 2013). One of our respondents noted that:

The reinsurance industry is where the ultimate carbon risk ends up...We're a primary insurer and life and pensions business, and there was recognition by my previous colleagues...that climate was an issue that could be material and was something that the firm should be getting their head around. [Financier D]

Insurance firms saw early action as one way of pre-empting subsequent claims against them by emitters, and the climate NGOs used this as leverage: 
One of the reinsurers...basically said, the first letter [from this CINGO] will be the letter to the chairman, that was delivered by FedEx - that would be exhibit A, if any companies ever get taken to court about climate change for the damage they've done to the world [Cingo A].

So while some clients may be particularly interested in climate issues due to their objective interests, the same applies to direct investors themselves because of the impact on their returns. Investors from the insurance industry will be especially focused on climate issues because their returns will be most immediately affected by climate risk. In the end, though, all investors will be affected - even certain hedge funds have recognized the risk to future returns, and a small number have financed a documentary on climate change (Delevigne 2014).

\section{Internal and external structure and agency}

The importance of agency exercised by corporate leaders was clear. A public example was Claude Bébéar, who created Entreprise et Cité (a group of business leaders who were motivated to sponsor humanitarian causes) in 1980 and then 1985 became CEO of the AXA Group. Examination of that company's website or documents reveals it is one of the leaders in ESG.

So it was that Financier D, a manager in one of the more activist CIIs we interviewed, said "There have been visionary people working here for a long, long time", and financier B, as mentioned, referred to "doing the right thing", not something normally built into the capitalist corporation. Most financiers we spoke to referred to the specialist units that they headed within their organizations, with differing reporting accountabilities (less influential ones, such as the "little unit" of Financier A, were a part of a "corporate affairs" group; some others reported to, or were even headed by, a Vice President). Financier E told us of several organizations that had cut down or closed ("mainstreamed") their specialist units in response to the European recession (see also Herzig and Moon, 2011; Mayhew, 2009).

Financier D noted how the structure of his organization, a large insurance company, was different to that of the majority of financial organizations, in that it was formed as the amalgamation of a number of "mutuals", and this enabled it to have a different perspective

Mutual status means that...the culture is somewhat different and they focus more on customers than they do on shareholders, because they don't have shareholders.

Because of that I think there is something to say around corporate culture being more long term and less focused on generating the quarterly numbers that get to the market [Financier D]

Thus not only external culture, but also internal culture, varies and matters. Most financier respondents spoke about the roles they played as specialists or that were played by their specialist units. It was also apparent how they were influenced by and networked with the ESG lobby groups such as PRI and CDP. As one respondent said, they were listening when "PRI has stepped up and said that this is what we (finance sector) need to be doing publicly" [Financier E]. One described CDP as their corporation's biggest ally for advancing climate issues [Financier D].

\section{Investment context: culture and economy}


The culture of investors' national context (in particular their home countries) was seen as influencing investor behavior. In particular, continental European investors and target companies were considered more sensitive to ESG issues than North Americans. As this became more evident we asked one of the interviewees why this might be?

Europeans are more receptive [to what we say] than North Americans.

Why?

Culture. It's more the psyche I think in Europe. It's more in their discussion. You hear it more in the regulatory system. You see it in the trade unions. You see it in the ethos. [Financier B]

Unions, of course, are stronger in most of Europe than in the USA, and in some countries they have financed research aimed at promoting long term strategies or sought to shape behavior of investors in which they can claim an interest, especially pension funds (eg Trades Union Congress, 2005). Institutions influence culture as well as reflect it. As Britain, an Anglophone culture on the edge of Europe, is one of the world's major financial centers, we also asked where British companies sat:

The British are happy to talk about governance as opposed to environmental and social. So they're more into specific governance as the lead in. So in that sense they do sit between Continental Europe and the US. [Financier B]

Cingo E emphasized the different cultures in London and continental Europe, in particular the Netherlands, which was like a "different planet":

People draw the line in different places when they're thinking about what might turn out to be financially material. And where you draw the line is going to be ... informed by all sorts of things, prejudice or whatever. I mean ... The frontline portfolio managers were just as hard-nosed financially in the Netherlands as they were in London, but partly because they were Dutch but also because of the investment strategies that they were running because of the nature of the institution, they were far more open minded about the kinds of information that might prove to be financially relevant or interesting.... they were prepared to, as it were to bring onto the decision making table information about climate change... Whereas the guys in London were far more likely to say, "What? You know, what the hell is the point of this?

That said, the context in Europe was also affected by the austerity crisis. First, while it was directly slowing down emissions due to low growth, this had led to the problems of the European emissions trading scheme that, according to Financier D, was failing and inefficient because the cap was set incorrectly. Second, austerity was diverting attention away from climate issues to other aspects of ESG:

In general, there's more a connection right now, especially in Europe, with social and governance issues because of the crisis. The crisis ties more into social breakdown of order and governance issues than environment. Environment is definitely on the top 
area. It comes up all the time, you see it in the media, but when you want to talk about it, I think people hit the, "God! Not again" button. [Financier B].

\section{Investment context: regulation}

Our interviewees saw state intervention as affecting investor behavior for several related reasons. First, regulation changes the way that target companies behave. In the USA, absent of regulation,

there is no clear regulatory impact related to carbon...there is nothing punitive ... there is nothing there! [Financier A]

Intervention therefore changes the nature of the interactions between CIIs and target companies. It enables CIIs to "to tackle environmental issues by making it a compliance discussion" [Financier B]. Hence, it changes the criteria that investors can apply in assessing profitable investments. We asked, what is needed?:

Regulation. It'd have to be regulation. We all respond well to it...If it is part of regulation people would pay attention. And disclosure then becomes part of security's regulations... The way you disclose and rules around disclosure, financial disclosure and the criteria and the timing of it... these things weren't really policy pieces 10 years ago. But after Enron... everything became a little bit more clear... Now you take disclosure for granted. You do it properly [Financier A]

Regulation. It's too hard for a player, let's say, to keep making the case that environmental issues matter when it takes so long to show that. [Financier B.]

Increased regulation:

would be the fastest change because it changes the whole framework...Individual behavior change is much harder to bring about by sort of moral persuasion, than providing a clear and stable framework in which to make decisions...that have really significant financial implications. [Financier C]

Thus some CII managers felt that greater intervention would make it easier for them to advance climate issues within their own organizations:

...We [the company] don't advocate for more regulation. We don't want more regulation but if you're asking me what I think would have to happen to shift (attitudes to long-term thinking), some form of regulation would be helpful... If we were mandated by the Securities Commission to account for the carbon risk in our portfolios, then we would do that... Then that would be something that investors would look at also. [Financier A]

Thus most of our respondents, from the bastion of deregulation, advocated state intervention and regulation: 
The government is driving the bus. If anything is to be done it is for the government to do it. For example....along the lines of a transition to a hybrid carbon tax [Financier E]

Several thought the European ETS was flawed for being inadequately interventionist, and not giving enough price signals to financial markets, with financier B claiming it had "not really put in the right incentive program". When asked what would help bring about a low-carbon society, one CII manager replied:

When [oil] prices rose to 140 US dollars per barrel, there was a reduction in consumption...Some of it [was] permanent)...with fewer cars on the road. A carbon tax would have the same effect in tackling energy consumption [Financier E]

Another went even further:

we're talking in terms of a 200 -euro price on carbon before you're properly starting to motivate the right kind of action through the market. [Financier D]

This same financier saw states as being a greater source of resistance to effective policy than "other financial institutions".

[states'] own earnings, are materially influenced by oil or tar sands. They aren't tripping over themselves to change the international economic structure so that these commodities stay in the ground....National oil companies, international oil companies...the extractor sector, energy intensive sectors like aviation or chemicals, those kind of sectors spend a huge amount of money and time influencing politicians and policy makers in a very professional way. You don't have the same counterbalance from the civil society sector, unfortunately. They're much louder and they're much noisier but they're less influential and less effective, as you can see from what was struck in Kyoto [Financier D].

The above quotes suggest that the common assumption held by many (including us) that finance capital was unanimously opposed to regulation must be modified. Climate change is an issue where many in finance capital see the market failure (promoting the short term at the expense of the long term) as so egregious that state intervention is required - and criticize states for failing to intervene.

\section{Discussion and Conclusions}

Various fractions of industrial capital often lobby for special state interventions to advance their interests, even while arguing for deregulation for others. Yet the interests of finance capital are usually served by universal deregulation. The contradiction we see arises because the issue at hand is one that concerns not just a single sectoral interest but the viability of the capitalist system upon which finance capital relies. Climate change places the objective interests of fractions of finance in conflict not only with those of other fractions of finance capital - those focused exclusively on short-term profit - but also those of important fractions of industrial capital, particularly those benefiting from uncontrolled emissions. Their interests may be united on many issues, but on this critical issue the divergence outweighs the commonality. 
While this explains the objective interests at play, we also need to explain influences upon changes in individual behaviors - in the "what" and "when" of investment decisions. There are many "myths" (Wright and Nyberg, 2013) and structural factors that inhibit an effective response to the threat of climate change. Changes are more likely: where reputation effects are potentially costly; where clients (individuals or pension funds) recognize the long term damage from climate change; where finance capital is operating in a sector where the effects of climate change are direct and most easily measurable (especially reinsurance); where structures within finance capitals give potential power to climate considerations; where key agents within those corporations exercise power to advance climate considerations (eg some individuals in leadership positions have corralled corporations into accepting responsibilities for sustainability and violations to the environment); where corporations are part of networks that provide them with the knowledge, tools, training and incentive to impose climate considerations onto target corporations; where regional or national culture is able to counteract the myths inhibiting action and instead place greater emphasis on longer term and broader considerations; where the state of the national economy leaves room for climate considerations; and, very importantly, where the regulatory context encourages or requires action. Some of these considerations suggest points of leverage for those interested in advancing climate issues: their self-perceived vulnerability to reputational issues; their responsiveness to the expressed interests of clients, especially pension funds; the role of networks including through climate-interested NGOs; the potential to influence key agents' actions through lobbying, education and awareness-raising; and, critically, the role of regulation. In turn, the contradictions within pension funds' own objectives provide a potential focus for action.

There also appears to be some spill over within finance: the growth of ESG discourse legitimizes CII behavior. Conversely, the location of climate discourse within a broader framework of ESG seems to result in CIIs taking account of ESG issues more generally, perhaps due to reputational effects, perhaps as a result of the need for some radical changes in paradigm to accommodate the implications of this long-term perspective. Whether the latter has occurred cannot be definitively answered here, but it raises some important issues for further research.

While dominated by finance capital, and despite the role of CIIs, the market if left to its own devices would tear itself apart and make capitalism unworkable - an insight attributed to Polanyi (1944) over half a century ago. Climate change, this area of inherent tension between the short-term and long-term interests of capital, raised questions amongst financiers and climate-interested NGOs we interviewed about the need for state intervention. Poulantzas (1980: 192) argues that depending on the power of class forces ranged against capital, the dominated classes can use the state to introduce policy that may not be in the short-term economic interests of the dominant classes. State regulation is centrally located in the issue of climate change. Without pricing of emissions, CIIs in the end cannot impose a new logic on the operation of finance capital. They can broaden the range of issues and lengthen the time frame for the fraction of capital they represent, but it is only through carbon pricing, and other regulatory interventions, that the logic of finance capital might be adapted to bring about effective action on climate.

\section{References}

Bakan, J. (2004), The Corporation: The Pathological Pursuit of Profit and Power, London: Constable \& Robertson 
Barker, T., P. Ekins, and N. Johnstone (2013), Global Warming and Energy Demand, Oxford: Routledge.

Carroll, R. (2013), Dozens arrested in Walmart protest as anger against retail chain escalates, Guardian, 9 November 2013.

Carroll, W. (2010), The Making of a Transnational Capitalist Class, London: Zed Books.

Carroll, W. K. (2007) Capital Relations and Directorate Interlocking: The Global

Network in 2007,

Chan, S. (2013), 'I am King': Financialisation and the paradox of precarious work, Economic and Labour Relations Review, 24(3), 362-379.

Cowan, D. M., Dopart, P., Ferracini, T., Sahmel, J., Merryman, K., Gaffney, S. \&

Paustenbach, D.J. (2010). "A cross-sectional analysis of reported corporate environmental sustainability practices." Regulatory Toxicology and Pharmacology, 58(3): 524-538.

Delevigne, L. (2014), Elite hedge funds: Wall Street is missing this one major risk, $C N B C$ Netnet, 26 April, http://www.cnbc.com/id/101611449

Donnachie, I. (2000), Robert Owen. Owen of New Lanark and New Harmony, London: Tuckwell Pres.

Entine, J. (2008), From Evil Empire to jolly green giant, Ethical Corporation, 4 July, http://www.ethicalcorp.com/communications-reporting/wal-mart-ethical-retailing$\% \mathrm{E} 2 \% 80 \% 93$-evil-empire-jolly-green-giant.

Esty, D., and A. Winstone (2006). Green to Gold: How Smart Companies use Evnironmental Straegy to Innovate, Create Value and Build Competitive Advantage. New Haven, Yale University Press.

Freeman, R. B. (2010), It's financialization!, International Labour Review, 149(2), 163-183.

Gauchat, G. (2012), Polarisation of science and the public sphere: a study of public trust in the United States 1974-2010, American Sociological Review, 77(2), 167-187.

Hansen, J., P. Kharecha, M. Sato, V. Masson-Delmotte, F. Ackerman, D.J. Beerling, P.J. Hearty, O. Hoegh-Guldberg, S.-L. Hsu, C. Parmesan, J. Rockstrom, E.J. Rohling, J. Sachs, P. Smith, K. Steffen, L. Van Susteren, K. von Schuckmann, \& J.C. Zachos, (2013), Assessing “Dangerous Climate Change": Required Reduction of Carbon Emissions to Protect Young People, Future Generations and Nature, PLOS, 8(12).

Henwood, D. (1998), Wall Street, London: Verso.

Herzig, C., and J. Moon (2011), Corporate social responsibility, the financial sector and economic recession, Research Report 86, Nottingham: International Centre for Corporate Social Responsibility (ICCSR), Nottingham University Business School.

Hmielowski, J., L. Feldman, T.A. Myers, A. Leiserowitz, and E. Maibach (2013), An attack on Science? Media use trust in scientists and perceptions of global warming, Public Understanding of Science, 1-10.

Hofstede, G. (1984), Culture's Consequences: International differences in work-related values, London: Sage.

Intergovernmental Panel on Climate Change (2007), Climate Change 2007: Physical Science Basis, Cambridge: Cambridge University Press.

Kahan, D. M., H.C. Jenkins-Smith, T. Tarantola, C.L. Silva, and D. Braman, (2014), Geoengineering and the science communication environment: A cross-cultural experiment, Annals of American Academy of Political and Social Science (forthcoming), available at SSRN: http://ssrn.com/abstract=1981907 or http://dx.doi.org/10.2139/ssrn.1981907 
KPMG International (2013), The KPMG Survey of Corporate Responsibility Reporting, Netherlands: KPMG Global Centre of Excellence for Climate Change and Sustainability.

Krippner, G. (2005), The financialization of the American economy, Socio-Economic Review, 3(2), 173-208.

Lever-Tracy, C. (2011), Confronting Climate Change, New York.: Routledge.

Lewandowsky, S., Oberauer, K. \& Gignac, G. (2013), Motivated Rejection of Science: NASA faked the moon landing-Therefore (Climate) Science is a Hoax: An Anatomy of the Motivated Rejection of Science, Pychological Science, 24(5), 622-633.

Liodakis, G. (2010), Totalitarian Capitalism and Beyond, Burlington, VT: Ashgate.

Lubin, D. \& D. Esty (2010). The Big idea: The Sustainability Imperative. Harvard Business Review 88(5): 42-50.

Macqueen, A. (2004), The King of Sunlight: How William Lever Cleaned Up the World, London: Bantam Press.

Mandel, E. (1972), Late Capitalism, London: New Left Books.

Marazzi, C. (2011), The Violence of Finance capital, Bellinzona, Switzerland: Edizioni.

Mayhew, M. (2009), Grim Days Ahead for Analysts, London: Integrity Research Associates, 2 February, http://www.integrity-research.com/cms/2009/02/02/1424/.

Nahser, F. B. (2013), Consumption in the Un-Commons, in Marketing and the Common Good: Essays from Notre Dame on Societal Impact, edited by P. E. Murphy and J. F. Sherry Jr, pp. 127-152, London: Routledge.

Ormiston, M. E., and E. M. Wong (2013), License to ill: the effects of corporate social responsibility and CEO moral identity on corporate social irresponsibility, Personnel Psychology, 66(4), 861-893.

Pearse, G. (2012), Greenwash: Big Brands and Carbon Scams, Melbourne: Black Ink.

Peetz, D., and G. Murray (2012), The Financialisation of Global Corporate Ownership, in Financial Elites And Transnational Business: Who Rules the World?, edited by G. Murray and J. Scott, Cheltenham: Edward Elgar.

Peetz, D., and G. Murray (2013), Financialization of corporate ownership and implications for the potential for climate action, in Institutional Investors' Power to Change Corporate Behavior: International Perspectives, Critical Studies on Corporate Responsibility, Governance and Sustainability, edited by S. Young and S. Gates, pp. 99-125, Bingley, UK: Emerald.

Polanyi, K. (1944), The Great Transformation: The Political and Economic Origins of Our Time, Boston: Beacon Press by arrangement with Rinehart \& Company, Inc. .

Poulantzas, N. (1980), State, Power, and Socialism, London: Verso.

Randall Morck (2005), A History of Corporate Governance around the World: Family Business Groups 500 pp., Chicago: University of Chicago Press.

Reguly, E. (2013), No climate--change deniers to be found in the reinsurance business, in Global and Mail, 28 November 2013, http://www.theglobeandmail.com/report-onbusiness/rob-magazine/an-industry-that-has-woken-up-to-climate-change-no-deniersat-global-resinsurance-giant/article15635331/?page=all.

Semenza, J., Ploubidis, G. and George, L. (2011), Climate change and climate variability: personal motivation for adaptation and mitigation, Environment Health, 10(46).

Stenhouse, N., M. Maibach, S. Cobb, A. Bleistein, P. Croft, E. Bierly, K. Seitter, G. Rasmussen, and A. Leiserowitz (2013), Meteorologists' views about global warming: A survey of American Meteorological Society professional members, Bulletin of the American Meteorological Society, 1-29. 
Strange, S. (1986), Casino Capitalism, Manchester: Manchester University Press.

Trades Union Congress (2005), Investment Chains: Addressing corporate and investor shorttermism, London: TUC, http://www.tuac.org/en/public/edocs/00/00/01/F5/telecharger.phtml?cle_doc_attach=566.

Vandenbergh, M. P. (2007), The New Wal-Mart Effect: The Role of Private Contracting in Global Governance, UCLA Law Review, 54, 913-970.

Wright, C., and D. Nyberg (2014), Creative self-destruction: Corporate responses to climate change as political myths, Environmental Politics, 23(2), 205-223.

1 The Vanderbilts were a very wealthy American family, especially prominent in the latter half of the nineteenth century. 